\title{
Early Uses of Computers in Schools in the United Kingdom: Shaping Factors and Influencing Directions
}

\author{
Don Passey \\ Centre for Technology Enhanced Learning, Department of Educational Research, \\ Lancaster University, UK \\ d.passey@lancaster.ac.uk
}

\begin{abstract}
This chapter describes the early development and introduction of computers into schools in the United Kingdom from the 1970s to the evaluation of their impacts and a shift in the focus of their uses in the 1990s. The chapter explores key factors influencing the direction and deployment of uses of computers in schools. It considers influences of national initiatives and policies, the development of support, support centres and central agencies, the involvement of hardware and software manufacturers and developers, different applications of computer resources, the focus of uses in the curriculum, and impacts on education. Conclusions drawn are that original intentions for the implementation of computers in schools were re-focused in the late 1990s, particularly as pedagogies and learning effectiveness were not strong drivers during the early implementation period.
\end{abstract}

Keywords: History of computers in schools, UK, early educational technologies, computers in schools initiatives, policy and practice drivers, software development, IT industry, national curriculum, IT curriculum.

\section{Introduction}

Technological developments and policy actions in the 1980s can arguably be said to have had the most long-term influence on uses of computers in schools in the United Kingdom (UK). Prior to the 1980s, computers were used in very isolated instances, but policy decisions and actions in the 1980s not only set in motion a string of events that led to much wider institutional and individual access, but also led to directions focusing forms and patterns of use.

This chapter takes a part personal, and part documentary, view of the factors and influences that were involved. The author, having used computers in schools in the early 1980s, then later became involved in research into uses of computers to support teaching and learning during that same period. This chapter offers a part historical, part developmental, part policy-driven, and part pedagogically-driven perspective. Personal experiences and reflections, supplemented by documentary evidence from key individuals, from policy and from research, offered through these different lenses, provides a picture that considers key factors and features:

- National policies: how they were developed and what they achieved. 
- Computer education support centres, professional development and other school support activities: their presence and roles.

- The contributions of computer companies, software designers and book publishers.

- Educational application software: their development and focus.

- Use of computers 'across the curriculum' in various subjects as well as for teaching computing: practical and policy contributions.

- How computers changed education (or did not change it) and why this happened.

\section{$2 \quad$ Policies and Practices}

In the 1970s and early 1980s a growing concern arose in the UK for greater awareness between and potential alignment of education with industry. This alignment was driven by a concern with three main factors: that the nature and forms of industry were changing, and that these changes needed to be understood by teachers as well as by young people moving towards longer-term societal involvement in training and employment; that technologies were becoming increasingly developed and deployed in industrial and commercial practices and their uses needed to be more widely recognised by those in education; and the uses of computers in education needed to be considered from the perspectives of commercial and economic potential. These concerns for alignment and wider gaining of understanding led to practices such as teacher placements in industry for limited periods of time, and the development of courses for young people that included more commercial and industrial content (such as Business and Technology Education Council courses). Machin and Vignoles [1] discuss these changes and their implications in the context of that period, giving a view of the levels of activity arising, stating that "Various initiatives attempted to replace the traditional apprenticeships ... These initiatives are too numerous to mention" (p.11). These initiatives included the creation of National Vocational Qualifications and General National Vocational Qualifications. Qualifications and courses were developed regionally and nationally, so in 1987, for example, the Department of Education Northern Ireland (DENI) funded an $£ 18 \mathrm{~m}$ Vocational Education Programme.

In terms of technologies in education during that period of time, isolated computers in some educational institutions (generally tertiary education) could be found in the early 1970s, but these large machines had limited capabilities, and students and teachers in schools only visited such premises to 'gape in awe' at the sight of processing power handled through valve-operated systems. In 1973 the National Development Programme in Computer Assisted Learning (NDPCAL), with a $£ 2.5 \mathrm{~m}$ budget over 5 years, ran over 30 projects across the tertiary education sector in the UK to explore a variety of potential applications of computer assisted learning (CAL) [2]. At the same time, the Computers in the Curriculum Project, funded by the Schools Council and based in King's College London, developed a range of interactive computer programmes in a number of subject areas.

While these projects developed software or computer programs, decisions to support education through program development were also linked with decisions to support the development of a wider potential computer industry (concerned with educational 
computing) itself. In the late 1970s, Research Machines (RM) developed microcomputers for schools, and the Apple II and the Commodore Pet were also created in the same period [3]. Indeed, the first computers in secondary and primary schools in the UK were Commodore Pets. These were used for spelling or arithmetic practice, as well as for programming in either BASIC or LOGO [2]. As Millwood [3] says,

"In the entrepreneurial science parks of Oxford and Cambridge, new companies emerged to build the microcomputers demanded by society, commerce and education, leading to the establishment of Research Machines, Acorn and Sinclair. At the same time, the Continuing Education Department at the BBC noted the rise of the microcomputer as a pervasive influence on society and began to propose a national campaign, which eventually became known as the BBC Computer Literacy Project, launched in $1982 "(p .10)$.

RM produced a $380 \mathrm{Z}$ machine from 1978, but, due to the high costs of machines from early developments, schools largely had to wait to the early 1980s for their chance to acquire a computer system, from a Department of Trade and Industry (DTI) initiative at that time. The initiative was supported by the then Prime Minister, Margaret Thatcher, when she stated in a speech in 1981 [4]: "Our future prosperity depends in large part on the quality of education today. That quality requires not only that children should learn the familiar basic subjects but that they should also be able to understand computers and how they can be used and applied." The initiative was called the Micros in Schools scheme, with funds of $£ 15.1 \mathrm{~m}$ in 1981 to 1982 to provide all secondary schools with half of the cost of a microcomputer. A follow-on DTI Micros in Primary Schools scheme similarly contributed half the cost of a cassette- or tape-driven machine (either BBC, RM480Z, or Sinclair Spectrum) for every primary school from 1982 to 1984.

Tape-driven machines were the first forms of computers accessible to schools. These gave way eventually to disk-driven machines. In 1983, the DTI provided $£ 2.1 \mathrm{~m}$ in funds for the Micros in Secondary Schools (Extension) initiative, so that schools could purchase printers, colour monitors, memory upgrades, disk-drives, and some other specified additional peripherals [2], and subsequently disk-drives became available for computers in primary schools in 1984. The issue for teachers at that time often was how to use such machines and their capabilities, but quickly some teachers (and some managers and administrators in schools) became interested in using these devices, exploring ways to extend not only what the technology could do, but also extending the ways certain concepts could be explored with learners (such as practising bacterial counts from example virtual microscope visualisations). In many cases initial users of these technologies had been teachers in mathematics, as there was initially less distance or distinction between software coding and application (which was perceived as a mathematical or logical problem arena). However, in some schools, teachers in other disciplines became interested in the potential for their subjects. With only one machine in a school at that time, this often led to challenges that teachers had not encountered before; a need to plan and book resources that would be school-based rather than classroom-based. Resources that would provide advice and guidance to schools on such management issues and possible approaches were to become a later major focus of research and development work, undertaken in 
some specific research centres [5], as well as in individual local education authority (LEA) centres [6].

Interest in the industrial and employment aspects of computers in schools led to a third government department becoming involved at an early stage. In 1983, the Technical and Vocational Educational Initiative (TVEI), was funded by the Department of Employment (DoE) at a level of $£ 20 \mathrm{~m}$, rather than by the Department of Education and Science (DES) as it was at that time. These initiatives focused on curriculum development and integration of design and technology approaches, initially for upper secondary school students (14 to 18 years of age predominantly). The TVEI and TVEI Extension initiatives supported schools in the development of courses and practices that focused on industrially-linked, technologically-integrated and design-driven approaches to subjects such as engineering, and design and graphics. Through these initiatives, schools were able to gain more and wider forms of technologies, including computer-controlled manufacturing tools. As the initiatives focused often on course development and integration, technologies were often grouped and retained within specific rooms (computer rooms) or resource areas (such as a design workshop). At the same time, however, growing interest in the application of technologies to support other support areas continued to emerge strongly. Indeed, the TVEI initiatives supported wider subject interest and practices, and groups of advisers and advisory teachers to support these initiatives, outside schools and located in LEAs, often developed and promoted uses of technologies not only in subjects across secondary schools, but also in primary schools. The growing interest in alignment of industrial change and future employment to education extended to concerns that teachers and learners in primary schools should also be involved in gaining wider awareness of the changes arising and their implications for their futures. By 1984 the deployment of computers in schools had reached a level that created a demand for and led to national funding and support for in-service training in what was then called information technology (IT) for teachers.

The DTI continued throughout the 1980s in providing funds to support schools in the acquisition of newly-developing technologies. In 1985 the DTI provided $£ 1 \mathrm{~m}$ in funds to provide a modem for every school, and subsequently, in 1988 a grant of $£ 140$ for each secondary school to install a telephone line for data communication. This was to be a significant turning point, and heralded and ultimately led to a major focus of development on networking capability for schools, exploring networking within schools initially. In 1987, the DTI provided funding of $£ 3.5 \mathrm{~m}$ to support the purchase of school IT equipment, managed by LEAs, for microcomputers (but only Acorn or BBC, Apricot, IBM and RM PCs), disk-drives, printers, mice, monitors, (significantly) teletext adaptors, and turtles and some other peripheral devices. From that time, the developing of networking, in schools and then across schools, was rapid. The first networks in primary schools were installed in 1992, a UK-wide networking of schools discussed in the Superhighways for Education consultation was launched in April 1995 and an evaluation of the potential of the initiative was published in 1997 [7]; from the late 1990s, networking was increasingly developed to link schools and regions nationally.

Across the entire period of time that these developments had taken place, schools and teachers were in a position to make decisions about whether or not to take part, and how they would use specific resources in classrooms. In 1989 a significant policy 
development in the UK was the creation of a national curriculum. For the first time, subject content was specified for all sectors of compulsory education, and the specification of this content was a learner entitlement curriculum that was statutory. In the specified national curriculum, IT was not presented as a separate subject area; it was contained within design technology [8]. But, the use of computers and technologies was also spread across and indicated within every subject area of the curriculum, at every age level, although it was focused heavily, as might be expected, in design technology. A TVEI research project based at Lancaster University created maps of information technology (IT) across the curriculum, showing for each Key Stage ( 5 to 7,7 to 11,11 to 14 , and 14 to 16 years of age) the statutory requirements for using IT in each subject area [9]. Within the design technology subject of the national curriculum [8], five aspects of IT capability were identified: developing ideas and communicating information; information handling; modelling; measurement and control; and applications and effects (p.73). For the end of each Key Stage, attainment targets and statement of attainment were identified at ten different levels, and an overall programme of study indicated what should be taught for learners to work at each of those ten levels. The national curriculum proposals were formalised in 1990 [10], and the programme of study within the technology in the national curriculum document rephrased what should be taught as: "communicate and handle information; design, develop, explore and evaluate models of real or imaginary situations; measure and control physical variables and movement" (p.45). Teachers were suddenly not able to choose whether or not to consider the uses of computers; as Griffin and Davies [11] said: "The National Curriculum makes explicit for the first time that each pupil has an entitlement to a curriculum which includes information technology (IT)" (p.255).

When the national curriculum was introduced in 1989, there was an early policy separation of the curriculum from assessment; so concerns with assessing uses of IT in subject areas (and indeed assessment concerns overall) tended in some respects to be separated from curriculum integration concerns. Some groups of LEA advisers, however, looked critically at this issue, and documentation began to emerge [12] that proposed how teachers could develop activities that would meet both curriculum and assessment requirements. The national educational technology support agency, the National Council for Educational Technology (NCET), also produced school support materials [13], and whilst assessment was covered in one of the eight booklets in that pack, this was indeed the last of the eight. It could be argued, therefore, that assessment was seen as an end product, and not as an integral element serving formative purposes.

Up to that time, strategic development of software and identification of appropriate pedagogies to deploy when using specific software had been considered to a limited extent. Prior to the national curriculum, software development tended to arise because of local interest and concerns (which had not been the case with the development of hardware and peripherals). From the time of the instigation of the national curriculum, there was a much greater focus on how the content of the curriculum could be supported by appropriate uses of software and technologies. Associated with this, a much greater consideration arose concerned with identifying appropriate pedagogies. Pedagogies applied to specific software applications at that time were being developed and were in practice, either through individual teacher endeavour, or 
through the practices developed and used by advisers and advisory teachers who were based in LEAs or more central national agencies. However, the centralisation of the curriculum created a more focused concern on the national identification of pedagogies and activities. The ways and reasons that support groups and agencies were developed, and their involvement in this focus, are discussed in the next section.

\section{Support and Uses}

In the early 1980s, when the concern and focus was on raising awareness and implications of shifts in industrial nature and practices, a part of the action taken to bring together and consider appropriate ways forward was the development of a national computer education support centre. In 1981 the DES set up the Microelectronics Education Programme (MEP), to support educational computing (initially focusing on developments in the secondary sector, but then in 1982 widened to include the primary sector). This programme was run through 14 regional consortia of LEAs, with another 4 Special Education Microelectronics Resource Centres (SEMERCs) [2].

In 1985 the DES provided $£ 2 \mathrm{~m}$ in funds to support LEAs through a more strategic focus, setting up the Microelectronics Education Support Unit (MESU), based in Coventry, sitting alongside Warwick University (that had already established a centre concerned with the future directions of education and work). In focusing on a more integrated strategic approach to developments of microelectronics, in 1988, MESU merged with the more higher education-focused Council for Educational Technology (CET), and NCET was formed, initially funded at a level of $£ 20 \mathrm{~m}$. This agency later became the British Educational Communications and Technology Agency (Becta) in 1997, which was more strategically linked to government policy directions. These units or agencies, over time, had become linked to greater extents to LEAs as well as to the government education department.

In the 1980s, the focus of support for the national units and agencies was supplemented with support initiatives at more local levels also. In 1987 the DES provided an Educational Support Grant (ESG), with funds of $£ 10.5 \mathrm{~m}$, to appoint some 650 advisory teachers in IT, to cover a range of curriculum subjects rather than the focus being on teaching IT. From 1988, MESU was provided with additional funding for induction training for these advisory teachers (including some librarians). Consequently, LEAs across England and their equivalents in the other nations (Wales, Scotland and Northern Ireland), used funds to establish their own advisory centres for computer and technology developments, headed often by an adviser of computer education, who headed up a team of advisory teachers as well as, sometimes, a technical team, either providing technical support to schools, or developing software and hardware applications for teacher use. The need for such centres to support teachers was clearly identified in the research literature of the time; needs to address management issues, skills needs, and pedagogical concerns were all highlighted. Heywood and Norman [14], for example, identified in 1988 major reasons why teachers did not use IT; these were mainly due to their lacking in confidence and competence is using IT. The authors noted at the time that, 
"Generally the programs in use were un-demanding in pedagogical terms with much drill and practice (especially in Mathematics), little database work, and no simulation exercises. The instructional nature of this software made little extra demand upon teacher time - the machines were switched on and left to the children, therefore requiring no teacher supervision" (p.41).

The funding for these LEA centres came through the DES, but there often were links with DTI initiatives providing funding through TVEI channels. That latter funding, however, ceased to exist to any great extent after the national curriculum was launched. IT matters beyond the launch of the national curriculum became the remit of the DES.

MESU and its successors promoted links with LEA advisers and advisory teachers. At the same time, in 1984, the advisers of computers in education established their own association, the National Association of Advisers for Computers in Education (NAACE) [15], which became a well-known body, regularly meeting with and advising government departments and agencies such as the National Curriculum Council (NCC) and the Schools Examination and Assessment Council (SEAC).

Additionally, with the launch of the national curriculum and the focus on IT in subject areas across the curriculum, subject associations also began to have increased interest in the development and uses of IT. Associations such as the Geography Association (GA) and History Association (HA), for example, set up their own internal focus groups to consider the applications of IT into subject and topic areas. In some subject areas, however, it was clear that a different focus was being suggested by the national curriculum for devices and software. Ball [16], when discussing implications of the national curriculum for mathematics teaching, said that "Before the advent of the National Curriculum, significantly more use in mathematics classrooms was being made of smaller, more focused programs than of spreadsheets or databases" (p.243). He highlighted the shift away from uses of calculators, adventure games, projects, games of strategy, exploratory activities and graph plotters, towards uses of content-free software.

While subject teachers in secondary schools were supported at a subject level for implementing IT needs of the national curriculum, teachers in primary schools faced very different challenges; as Govier [17] said, "primary school teachers are teachers of English ... and mathematics ... and science ... and technology ... and history ... and geography" (p.163). She concluded that "the demands made by the National Curriculum on the IT skills of primary teachers ... are, in the short term, quite impossible to meet" (p.162).

The development of policies and support structures over time, alongside the identification and implementation of measures to address school and teacher needs as they were arising, was coupled of course with the ways that computers and technologies were themselves being developed. In the next section, parallel technological development features and factors will be outlined and considered, before bringing this back in the subsequent sections to concerns about teaching, learning and pedagogies. 


\section{Computer Companies and Commercial Concerns}

When computers first arrived in schools, there was little choice of machine. At that time key companies involved in developing machines were: Research Machines (RM) who had developed the 380Z; Sinclair; and the BBC who produced the BBC machine. The interest of the BBC was discussed earlier in this chapter, and from part of that interest, in 1981, the BBC awarded a contract to Acorn to produce a Personal Computer (PC), which ultimately became particularly popular in schools. Indeed, by 1986, some 650,000 BBC Model B computers (the successor of the original BBC machine) had been sold. Within a relatively short time, however, a number of other key computer companies were involved in producing machines to meet the needs of specific initiatives, that schools could acquire by choice. In reality, however, many decisions about choice were deferred to LEA advisers or advisory teams. LEAs then tended to become either: PC-based, often with RM machines; BBC-based, with Acorn machines; or Macintosh-based, with Apple machines. There was an involvement of some other computer producers, such as Apricot and IBM, but their reach into schools was much lower than the three main producers mentioned above.

From 1975, computers that educational institutions could acquire changed in terms of significant features they offered about every 5 years. These are shown in Table 1 .

Table 1. Features of computers accessible to UK educational institutions since 1975 [18]

\begin{tabular}{ll}
\hline From the year & Features of accessible computers \\
\hline 1975 & $\begin{array}{l}186 \text { machines, BBC machines, standalone, using cassette and tape } \\
\text { programmes }\end{array}$ \\
1980 & $\begin{array}{l}286 \text { machines, BBC B machines, using 5.25 inch disks } \\
1985\end{array}$ \\
1990 & Laptop machines, Acorn machines, with local networking \\
& ROM), 3.5 inch disks \\
1995 & 486 machines, 586 machines, Internet access, colour printers, \\
& shared software \\
\hline
\end{tabular}

Looking at this in terms of deployment and access, major technologies adopted in UK schools from 1975 not only had different features, but could also be deployed in ways that could affect both their access and the ways that teachers would use them and effect pedagogies with learners. From 1975, calculators could be used on a oneto-one basis; from 1980, standalone micro-computers could be deployed as shared items across a school or a class; from 1985, suites of micro-computers could allow half classes or groups to access them; from 1990, networked micro-computers with enhanced graphics could allow work to be retained and shared to greater extents. In 1993, there was a first trialling of portable computers in primary and secondary schools and in teacher training institutions in England, and the Acorn Pocketbook Psion Series 3 was the first small computer to be used in schools that year [2]; and from 1995, Compact-Disk - Read Only Memory (CD-ROMs) and integrated learning systems (ILSs) could enable access on a one-to-one basis for specific periods of time during a day [18]. 
Across this period of time schools acquired increasing numbers of computers. By 1989 the ratio of computers to learners in primary schools had reached 1:67 and in secondary schools 1:28. The focus on hardware during the 1980s was succeeded by a focus on software. The development of software to fulfil subject curriculum needs was at a height during the late 1980s, and much of the early development was undertaken by centres in universities as well as in advisory centres in LEAs. In some cases, small companies began to be established, which focused on more specialised software, perhaps to support learners with special educational needs. In some cases, these focused on hardware developments rather than, or as well as, software developments. Peripheral technology devices to support specific impairment needs, for example, were focally developed during that time period. Software designers often began their careers in professional development or advisory centres in LEAs, and the rise of small-scale companies developing software, grouped with hardware producers focusing on educational hardware developments, meant that the link between industry and education was becoming strongly established, but focused specifically on educational technologies. The industries of educational technology emerged, but these industries were much more specifically focused and at the same time more narrowly linked to wider commercial IT companies.

\section{Software}

It can be argued that the development of computers and technologies has followed a development path that has enabled a shift from information to communication, and from shared to individual access. The shifts in terms of software over that period are far more complex. Using a recent taxonomy of digital resources to consider forms of software accessible to schools from about 1980 [19], Table 2 summarises the ways in which specific categories of software have been accessible to and used by teachers. The software resources are roughly chronologically listed, to give an idea of the shifts in or progression of software categories over time.

Table 2. Accessibility and use of different categories of software by teachers in schools from about 1980

\begin{tabular}{|c|c|}
\hline Category of software & Accessibility and uses by teachers \\
\hline Television and video & $\begin{array}{l}\text { Television and video pre-dated uses of computers and } \\
\text { software in schools. To some extent schools replaced their } \\
\text { uses of television and video with software (or through their } \\
\text { access to digital resources more recently). Television and } \\
\text { video resources have tended to focus on specific topics, but } \\
\text { they have often provided a 'big picture' as well }\end{array}$ \\
\hline Calculators & $\begin{array}{l}\text { Calculators also pre-dated uses of computers and software. } \\
\text { As they became more sophisticated, they were used for more } \\
\text { graphical functions, but are now widely incorporated into } \\
\text { computer resource systems }\end{array}$ \\
\hline
\end{tabular}


Topic-specific resources Much of the early software accessible and produced by and software advisory and small development companies was topic based. This development approach was reinforced when the national curriculum was implemented, with many resources being developed to support specific topics within specific subject areas. However, at the same time, generic contentfree software was highlighted within national curriculum documents

Word processors Word processors have been widely used across the entire period of time that software has been used in schools in the UK

Games-based activities Many (even early) software packages have taken a gamesbased approach. This was particularly the case when graphics functionalities of computers were enhanced in the mid-1980s. Games-based activities have tended to be linked to topic-specific software

Simulations and Simulations and modelling software was developed at an modelling early stage by King's College London, and by the Computer Based Modelling Across the Curriculum Project [20], particularly focused on supporting teachers in science, mathematics, geography and business education

Project and after-school Some of the early uses of software, due to there often being club activities involving only one computer accessible, focused on project-based digital technologies approaches, sometimes involving clubs and events after school or at break times. More recently, these forms of resources and approach have tended to become more limited Curriculum-wide ILSs, comprising activities to cover an entire subject learner-centred software curriculum, became very popular in the early 1990s. (ILSs) Evaluation studies of these forms of software that originated in the United States were conducted initially by NCET in 1994 [21], but after a period of some five years, their use declined dramatically

Curriculum-wide Much of the early software was developed for learner use teacher-centred software rather than teacher use. Teachers often had to find ways to use software with learners, and to develop appropriate pedagogies. Indeed, teachers often 'left learners to use the programs' or 'allowed learners to use the programs on the computer in the corridor'. It was not until networking access became feasible that teacher-centred software tended to be developed

Projects focusing on Projects of this nature have been developed since broadcasting networking and Internet accessibility have been possible. Increasingly, major broadcasting companies and corporations have become involved in these projects, such as the BBC News School Report projects that are run annually 
Online resources supporting curriculumwide needs

Online resources supporting revision needs

Software involving and supporting parents

Online learner support

Projects linking schools and learners internationally

Projects developing video-game elements
These resources were largely not developed until Internet access was feasible. Local networking did not tend to promote the development of software resources to support this form of interaction

These resources were developed more recently, since Internet access has enabled learners to use these resources in a variety of locations

This was not a major thrust of the software development at early stages of implementing computers into schools. It has been a recent focus for some providers

This is a very recent development, and is likely to widen in scope in the future

Similarly, this is a very recent development, and is likely to widen in scope in the future

These projects in schools have only very recently been developed, and are likely to widen in scope in the future

It is notable, perhaps, that from the early stages software development did not involve book publishers largely. The concept of resources being technologicallybased or hardcopy-based remained and was retained over decades from the 1980s (and indeed in the 2010s the book publishers are still concerned with how to most effectively develop wider forms of technologically-based published resources).

Software development and availability in schools has been supported through national funded initiatives. In 1985 , the DTI provided $£ 3.5 \mathrm{~m}$ in funds for a period of 3 years for the purchase of software, to be match-funded and managed by LEAs. In terms of the software available at that time, forms of educational application software that were developed in the 1980s tended to focus very heavily on specific subject topics, and although there was rapid development of software, limited functionality in graphics at the time limited the scope of software applications. Researchers were reporting in the late 1980s about long-term development features that they felt should be considered to ensure ease of future production and accessibility to software. Nicolson [22], for example, proposed a system of development that enabled a host machine to produce software that could be transferred to other machines, with the Acorn BBC microcomputer as the target machine identified at that time. It should be noted particularly that compatibility of developed software with a range of hardware machines was a key challenge at that time. It was not until 1990 that multimedia PCs became available to schools. CD-ROMs were developed from 1992, and the DES supported a number of specifically funded initiatives at that time, that focused on compatibility as well as on software development.

Research undertaken by Harris and Preston [23] in 1993 reported, from a survey across 196 primary and 292 secondary schools, that for both sectors the major influences affecting software purchase were levels of IT budgets, national curriculum requirements and school IT policy and development plans, and that all these factors were more prominent than LEA policies. The sources of software indicated by schools clearly did not include major book publishers notably; Sherston, Resource, SPA, AVP, Reckitts, Capedia, Longman Logotron, Macline, NCET and TAG were noted specifically as sources used by schools (p.18). However, primary schools noted 
that their main sources of software came through LEA computer centres, while direct commercial sources were more prevalent for secondary schools. Primary schools indicated that they mainly had computer facilities located within classroom areas; for secondary schools, teachers of mathematics, English and religious education reported most access in computer rooms, while teachers of science, design technology, music, art and special educational needs reported more access in classrooms.

The Harris and Preston report [23] indicated the prevalence of use of different forms of software in schools. These are shown in Table 3 for primary schools and in Table 4 for secondary schools.

Table 3. Types of software and their reported high levels of use in primary schools (Source: [23])

\begin{tabular}{ll}
\hline Type of software & Percentage of teachers reporting high levels of use \\
\hline Word processing & 67 \\
Adventures and simulations & 24 \\
Databases & 23 \\
Computer-aided art or design & 20 \\
Programming (e.g. Logo) & 6 \\
Desk-top publishing & 5 \\
Spreadsheets & 3 \\
Computer-aided musical & 2 \\
composition & \\
Measurement and control & 1
\end{tabular}

Table 4. Types of software and their reported high levels of use in secondary schools (Source based on: [23])

\begin{tabular}{ll}
\hline Type of software & Subject teachers reporting high levels of use \\
\hline Word processing & $\begin{array}{l}\text { Used across the curriculum, but mainly by special educational } \\
\text { needs, English, design technology, and science teachers }\end{array}$ \\
$\begin{array}{l}\text { Adventures and } \\
\text { simulations }\end{array}$ & $\begin{array}{l}\text { Limited use across the curriculum, with most use by special } \\
\text { educational needs and mathematics teachers }\end{array}$ \\
Databases & $\begin{array}{l}\text { Limited use across the curriculum, with most use by mathematics, } \\
\text { design technology, music, geography and science teachers }\end{array}$ \\
Desk-top & $\begin{array}{l}\text { Used across the curriculum, but mainly by design technology, } \\
\text { publishing }\end{array}$ \\
English, religious education and special educational needs \\
teachers \\
Spreadsheets & $\begin{array}{l}\text { Limited use across the curriculum, with most use by mathematics } \\
\text { and design technology teachers }\end{array}$ \\
\hline
\end{tabular}

During the 1980s many questions were raised by teachers about the value of using software - including what was to become the most popularly used form of software, word processors. Researchers often undertook studies across this period that looked at uses and their outcomes in terms of teaching and learning. Pearson and Wilkinson [24] in 1986 reported a study on uses of word processors, and concluded that:

"The word processor was not found to be an essential prerequisite to such revision, but appeared in these cases to act as a facilitating device which increased the motivation to revise by making it so simple. The contention 
that word processors may only encourage children to tinker with surface features of their writing is not borne out by the evidence of these case studies. On the contrary, from this sample the implications are that for children who are as it were at a point of readiness to develop further in their writing, the word processor may be a most useful writing instrument which could catalyse that progress" (p.187).

Certainly in the 1980s the range of software available to schools was limited. When the national curriculum was introduced in 1989 , the DES provided $£ 750 \mathrm{k}$ in funds to develop new software titles to help teach national curriculum subjects. Research from the period shows how computers and software were deployed, the ways teachers across a school were able to share resources, and to develop practices that would enable individual, groups or classes of learners to gain from the software available. It can be argued that the early deployment patterns of computers supported direct and focused learner engagement and that this was a leading focus of program developers, rather than leading to an alternative focus on teacher engagement and on ways to consider appropriate pedagogies. Indeed, in a paper by Robson, Steward and Whitfield [25], the discussion about use of software is entirely around concepts of learner decisions when encountering and using a program, and how learner autonomy might be developed more in the future, rather than considering the roles of teacher support. The reasons for a learner-centred focus, however, are understandable; as Gibbons [26] concluded from her review of barriers and challenges in using BBC microcomputers in a school, once teachers had overcome the challenges of availability and accessibility of hardware, and felt confident enough to try to use a piece of software, then still the major obstacle remained, "There is little to help the inexperienced teacher in planning and anticipating the learning situation" (p.27). Teachers basically needed often to "try IT out' and work out for themselves what pedagogies to use and what learning outcomes or intentions to consider for their learners.

It can be argued that how IT was used during the 1980s was developing pedagogies, and indeed the concept of IT being a 'Trojan horse' was developed from that period of time. In other words, the need for teachers to develop pedagogies that would accommodate low levels of access to IT was seen as being particularly valuable, because it meant that teachers would develop useful pedagogies around practices that would involve and lead to the benefits arising from group work, team work, shared activities, and sequential work. As Johnston reported in 1987 [27] in the context of teaching language development:

"The ways learning and teaching are altered by the introduction of software which enhances or extends the existing curriculum, offering new opportunities for classroom activities and involving a redefinition of the roles of teacher and pupil, are frequently referred to. Sometimes this is with confidence, but equally frequently the teachers express reservations concerning a perceived loss of control of pupil learning" (p.144).

Yet the author went on to say from the same research evidence that "The most effective use of a microcomputer is found by the practising teachers to depend upon a learner-centred educational philosophy and approach" (p.144). Indeed, the author pointed out earlier in the paper that the three most suitable areas for IT enhancement for language development were in creative writing, discussion and oral work, and 
vocabulary extension, where there are clearly opportunities for learner-centred approaches. The emphasis of learner-centred approaches with uses of computers is highlighted in other research findings too. Rogers [28], in the abstract of a paper exploring how IT can be used in science in the National Curriculum, certainly states how learner-centred approaches could be supported through applications of software, saying that: "An investigative and exploratory approach to learning science is emphasised in the National Curriculum. This paper discusses the role of Information Technology in encouraging the methods of inquiry suited to this approach" (p.246). The author discusses how data-logging, spreadsheets, databases and simulations can all support a curriculum that is learner-centred (where the learner undertakes activities and the handling of data and information).

\section{Computers and the Curriculum}

Undoubtedly the curriculum and its associated assessment have been major drivers in terms of how computers, technologies and digital resources have both been developed and deployed in schools, classrooms, and by teachers. The use of computers was, almost from the outset, not just concerned with use in an IT subject, but in any subject. Many secondary schools in the 1980s did start to develop IT as a subject, however, and created computer or IT rooms. In some schools, even well into the 1990s and beyond, subject teachers who were not IT teachers found they had limited access to computers and technology-based resources. Even so, from 1989, the idea of IT 'across the curriculum' was felt by many advisers and teachers to be worthwhile, but practically difficult to achieve. HMI Curriculum Matters 15 - IT from 5-16 [29] was published that year, recommending schools to look at uses of IT across the curriculum, and to consider how to do this by developing a coherent strategy 'for making effective use of IT as an enrichment of the curriculum'.

This concept of 'across the curriculum', with use in any or all subjects, became a major focus of attention during the late 1980s, when the numbers of computers in schools had increased, but also concepts of cross-curricular value were being highlighted more generally within educational practices. Some software at that time was developed to be 'cross-curricular', that is, it did not have a specific subject focus, but covered a range of topics in a number of subjects. Software such as problembased, simulations and modelling, developed in the late 1980s, for example, enabled teachers to undertake activities that were cross-curricular in nature rather than subject based. The national curriculum, and its subsequent assessment, both through national tests and external inspection of schools, however, tended to raise questions about the time that teachers should devote to cross-curricular activities and to devalue the crosscurricular and project-based approaches, so that schools and software developers tended to focus increasingly on producing subject and topic-based resources and software. The national curriculum in 1989 supported an 'across the curriculum' direction; as Griffin and Davies [11] said, "The curriculum should ensure that each pupil uses IT to enhance and enrich his or her learning in every area of the curriculum" (p.256). Schools also increasingly embraced IT teaching more; and indeed the Qualifications and Curriculum Authority (QCA), which was the merged successor of NCC and SCAA, published a scheme of work for IT. In many respects 
this document created a uniformity of teaching and activities for IT across schools, however, rather than generating a variety of activities and approaches.

Once a national curriculum approach had been implemented, national evaluation became much more prominent; in essence, a national curriculum appeared to support the notion that some forms of national uniformity could be identified that could be measured. In 1991 Her Majesty's Inspectorate published a report [30] on the uses of IT in teaching and learning in primary classrooms. This report highlighted how some more prevalent uses of IT had shifted over time. They stated that: "the best practice and the most application of IT was in handling text", but " data-handling, control and LOGO applications produced some of the most exciting work, but only slight use was made of them" and "there were marked changes in the way in which many schools used IT" (p.10). This report also indicated the fact that software use can be short-lived rather than long-standing: "Certain programs achieved widespread, if short-lived, popularity" (p.12).

The roles of research in driving the direction of uses of computers in schools is hard to quantify, but certainly it is clear that not only have certain research centres developed software that has had significant uses in schools, but they and other research centres have focused on the ways that software and computers have enhanced and supported learning (and indeed, many researchers have been involved in studies that have explored how IT has supported teaching and learning, such as those at King's College in the original ImpacT study [31]). Some research centres have focused on specific pedagogical concepts, while others have looked more widely across pedagogies and their uses in schools. But the distinction (and tension) between 'teaching about IT' and 'using IT to support learning' remained during this period. The Dearing review of the national curriculum in 1993 [32] certainly identified IT as a key future need, saying that "Each National Curriculum subject should continue to be taught in the first three key stages, but the review should recognise the prime importance of mastery of the basics of learning at the primary stage, including literacy, oracy, numeracy and a basic competence in the use of information technology" (p.8). But the statement was argued by some to be more concerned with 'the teaching of IT' than 'using IT'.

By 1997, government ministers were openly talking about the linking of uses of IT to wider concerns with learning, attainment, effectiveness and the raising of standards. A clear shift had arisen by that time; from a concern about raising awareness about the potential of computers and IT, to raising attainment in subject terms. Information and communications technologies (ICT) were then identified as a fourth basic skill. It could be said that 'a new era was emerging'. ICT was being seen as fundamental to learning, rather than it being seen as supporting raising awareness of potential for training and employment. During the 1990s the levels of computers and technologies in schools increased. By 1999, statistics from The Stationery Office [33] indicated that the ratio of a computer to learners in primary schools was $1: 16$, in secondary schools it was 1:8, and in special schools it was 1:4. In that same report, $62 \%$ of primary, $93 \%$ of secondary and $60 \%$ of special schools were connected to the Internet, $15 \%$ of primary, $32 \%$ of secondary and $14 \%$ of special school teachers had their own e-mail addresses, and $68 \%$ of primary, $66 \%$ of secondary and $68 \%$ of special school teachers felt confident in using ICT in the curriculum. This marked a 
significant shift from one teacher in some schools being aware of and interested in computers in the early 1980 s.

\section{Outcomes, Impacts and Directions}

Computers have undoubtedly changed education in some respects, but interestingly, not in others. In terms of the original conceptions for introducing computers, no known specific evaluation of these has ever been completed. So, whilst the original intention was to develop wider awareness of industrial change and breadth of uses of computers, there is no specific evidence gathered to identify whether this actually happened. Whilst computers and technologies have become more prevalent in schools, and have been used by teachers and learners increasingly, it is not clear that this shift has enhanced awareness of industrial change, or the ways that technologies are used in industry or could be developed further. Indeed, it could be argued that whilst the development of an educational technology industry has undoubtedly happened and been successful, that this has focused the attention of teachers and learners on educational technology rather than opening up awareness to wider potential uses or enabling a focus on the development of innovation beyond education. It was the DTI that supported schools in purchasing computers, but without the DTI's continued involvement and interest in maintaining their focus, it is not clear that their long-term intentions were or could be fulfilled.

Computers have changed education in terms of resources and facilities available, in terms of a wider use of visual and auditory resources, and in terms of increasing potential uses of networking in a more modern context. But facilities have changed far more than pedagogies; but in the defence of teachers, it can also be argued that a subject content curriculum maintains a subject pedagogical focus rather than asking teachers and educators to focus on pedagogy and learning process. Johnston [34], back in 1987, highlighted this issue, stating that evaluation of microcomputer programs then lacked focus on "the nature of the learning experiences offered" (p.45).

Policy has driven the role of computers to a large extent. But the dramatic and frequent changes that occur with technologies themselves have not been something that has been taken up and addressed within educational policy. Policy continues to look back to a greater extent than looking forward; it is tactical rather than strategic, so whole realms of potential have been lost as a consequence.

The development of a national curriculum shifted local technology development to national technology development. Uses of computers and technologies at a local level were overshadowed by concerns with identifying national pedagogies and activities. This is not how technologies work in industry or in driving innovation; it is the specifics and the local context and detail that are important. Innovation is unlikely to arise from just a fulfilment of national activity.

Findings from a key national study published in 1993 [31] indicated that levels of computer access and use were important if learning outcomes were to be heightened. Actually evidence of the impact arising from higher levels of use and access has not definitively been identified; it still remains clear that what is done with a computer determines impact at an individual level rather than there being a formula of access and level of use that determines impact. In this respect, the development of communication 
facilities opens up different opportunities; levels of access are important here, but the quality of interactions and outcomes is not solely a result of that level.

The development of software across this early period of computers being used in schools shows that topic-specific and project-based activities were superseded to extents by uses of more open and content-free software. Although it can be argued that content-free software enables a wider application and opens up the possibilities for application innovation and creativity more, it can also be argued that ideas of 'a big picture' about a topic and the benefits of team working and project working have been reduced. It is clear that software developed during the early periods of computer use in schools was certainly more learner-focused than teacher-focused; unsurprisingly, it was found that pedagogies were much more difficult to develop.

Even the involvement of research has shifted across this period of time. Initially research centres were concerned with technology and software developments; these gave way to concerns with pedagogical and evaluation focuses. The national curriculum created concerns for and conceptions of national evaluation. The idea of the local innovation is not so clear within a focus that requires an identification of potential national practices.

History shows us that our intentions can be good, but if we change these intentions and do not follow them through for a reasonable period of time, then we may lose the possibility of gaining the potential we initially sought. It can be argued that the original intention of gaining wider awareness of industrial and employment change, and developing learners who could take forward interests in innovation and development, has been refocused to a much more specific use of computers within narrow areas of curriculum. Is it time to rethink the position again, and to promote the idea that education should once again partner industry in order to look to consider and address needs of the future?

\section{References}

1. Machin, S., Vignoles, A.: Education Policy in the UK. Centre for the Economics of Education, London School of Economics, London (2006)

2. Crapper, S.: Personal communication (2010)

3. Millwood, R.: A short history off-line. Becta, Coventry (2009)

4. Thatcher, M.: Speech on microcomputers in schools. Margaret Thatcher Foundation (1981), http: / / www . margaret thatcher.org/document/104609

5. Whole School Development in IT Project: Whole school IT development. Kent IT in Schools County Support Team, Sittingbourne (1991)

6. Birmingham City Council Education Department Curriculum Support Service: Information technology in your schools. Birmingham City Council Education Department, Birmingham (1990)

7. Scrimshaw, P.: Preparing for the Information Age: Synoptic Report of the Education Departments' Superhighways Initiative. Welsh Office, Department of Education for Northern Ireland, The Scottish Office, Department for Education and Employment, Cardiff, Belfast, Edinburgh, London (1997) 
8. Department of Education and Science and the Welsh Office: National Curriculum Design and Technology for ages 5 to 16 - Proposals of the Secretary of State for Education and Science and the Secretary of State for Wales. Department of Education and Science and the Welsh Office, London (1989)

9. STAC: Mapping of IT: A View Across The Curriculum. Lancaster University, Lancaster (1990)

10. Department of Education and Science and the Welsh Office: Technology in the National Curriculum. Department of Education and Science and the Welsh Office, London (1990)

11. Griffin, J.A., Davies, S.: Information in the National Curriculum. Journal of Computer Assisted Learning 6, 255-264 (1990)

12. Advisory Centre for Computers in Education: Teacher assessment of I.T. capability at Key Stages 1, 2 and 3 - Planning for assessment. ACCE, Cardiff (1992)

13. National Council for Educational Technology: School-focused development materials for Key Stages 1, 2 and 3 - Focus on I.T. NCET, Coventry (1991)

14. Heywood, G., Norman, P.: Problems of educational innovation: the primary teacher's response to using the microcomputer. Journal of Computer Assisted Learning 4, 34-43 (1988)

15. Naace: A brief history of Naace. Naace (2013), http: / /www . naace. co . uk/257

16. Ball, D.: What is the role of IT within the National Mathematics Curriculum? Journal of Computer Assisted Learning 6, 239-245 (1990)

17. Govier, H.: IT in Primary Schools - the opportunities of the National Curriculum. Journal of Computer Assisted Learning 7, 162-169 (1991)

18. Passey, D.: Strategic evaluation of the impacts on learning of educational technologies: Exploring some of the issues for evaluators and future evaluation audiences. Education and Information Technologies 4(3), 223-250 (1999)

19. Passey, D.: Inclusive technology enhanced learning: Overcoming Cognitive, Physical, Emotional and Geographic Challenges. Routledge, New York (2013)

20. Computer Based Modelling Across the Curriculum Project: The Modelling Pack - Teacher resources for Computer Based Modelling in Science, Maths, Geography and Business Education for Key Stages 3, 4 and 16+. NORICC and The Advisory Unit Computers in Education, Newcastle-upon-Tyne and Hatfield (1992)

21. National Council for Educational Technology: Integrated Learning Systems - A Report of the Pilot Evaluation of ILS in the UK. NCET, Coventry (1994)

22. Nicolson, R.I.: A short-term plan for CAL. Journal of Computer Assisted Learning 3, 81-88 (1987)

23. Harris, S., Preston, C.: Software in schools. NFER, Slough (1993)

24. Pearson, H., Wilkinson, A.: The Use of the Word Processor in Assisting Children's Writing Development. Educational Review 38(2), 169-187 (1986)

25. Robson, E.H., Steward, A.P., Whitfield, G.E.: Pupils' choices in learning with computers. Journal of Computer Assisted Learning 4, 93-102 (1988)

26. Gibbons, L.: Escape or Run? Journal of Computer Assisted Learning 2, $22-27$ (1986)

27. Johnston, V.M.: Attitudes towards microcomputers in learning: 2. Teachers and software for language development. Educational Research 29(2), 137-145 (1987)

28. Rogers, L.: IT in science in the National Curriculum. Journal of Computer Assisted Learning 6, 246-254 (1990)

29. Her Majesty's Inspectorate: Curriculum Matters 15: 1T from 5 to 16. HMSO, London (1989)

30. Her Majesty's Inspectorate: Aspects of Primary Education - The teaching and learning of information technology. Department of Education and Science, London (1991) 
31. Watson, D.M. (ed.): The ImpacT Report - an evaluation of the impact of information technology on children's achievements in primary and secondary schools. Department for Education and King's College Centre for Educational Studies, London (1993)

32. Dearing, R.: The National Curriculum and its Assessment - final report. SCAA, London (1993)

33. The Stationery Office: Statistics of Education - Survey of Information and Communication Technologies in Schools 1999. The Stationery Office, London (1999)

34. Johnston, V.M.: The evaluation of microcomputer programs: an area of debate. Journal of Computer Assisted Learning 3, 40-50 (1987) 